\title{
KSIAZZKKA JAKO ELEMENT WARSZTATU NAUKOWEGO I PRZEDMIOT REFLEKSJI POZNAWCZEJ U HISTORYKÓW POLSKICH XVII WIEKU ${ }^{1}$
}

W polskiej barokowej erudycyjnej historiografii XVII wieku zbliżonej do europejskiego nurtu krytycznego, książka spełniała różne funkcje. Przede wszystkim pełniła rolę źródła historycznego. Zgodzić się trzeba ze spostrzeżeniami Jerzego Serczyka, iż jeszcze w pierwszej połowie XIX wieku, trudno było mówić o dokładnym rozróżnieniu między źródłem narracyjnym, a opracowaniem ${ }^{2}$.

W niniejszych rozważaniach uwaga zostanie poświęcona zaledwie kilku historykom: Stefanowi Damalewiczowi, Janowi Krzysztofowi Hartknochowi, Stanistawowi Łubieńskiemu, Pawłowi Piaseckiemu, Szymonowi Starowolskiemu i Stanisławowi Szczygielskiemu. Ten wybór podyktowany został względami, iż swoje badania naukowe prowadzili w oparciu o źródla aktowe, co korespondowało z przodującymi ośrodkami historiografii europejskiej. Podobnie jak czołowi historycy europejscy tego czasu, którzy spędzali swoje życie wśród książek i bibliotek ${ }^{3}$, niektórzy z wymienionych badaczy także żywo interesowali się zagadnieniem książek i byli bibliotekarzami. Rozważania merytoryczne należy poprzedzić krótkimi charakterystykami biograficznymi.

Stefan Damalewicz urodzony na początku XVII wieku, zmarł w roku 1673. Był wychowankiem Akademii Krakowskiej. Po uzyskaniu święceń kapłańskich pełnił posługę duszpasterską w diecezji włocławskiej, ciesząc się protekcją biskupa Macieja Łubieńskiego. W roku 1642 wstapił do klasztoru kanoników regularnych w Kodawie. Brał udział w toruńskim colloquium charitativum oraz uczestniczył w kapitule generalnej kanoników laterańskich w Rawennie. Najważniejsze jego dzieła: „Series archiepiscoporum Gnesnensium”, Warszawa 1649, „Vita S. Bogumili archiepiscopi”, Rzym 1611, „Vitae Vladislaviensium episcoporum”, Kraków $1642^{4}$.

Jan Krzysztof Hartknoch żył w latach 1644-1687. W roku 1672 uzyskal tytuł magistra w Akademii Królewieckiej. Zajmował stanowisko profesora w Gimnazjum Toruńskim. W przeciwieństwie do reszty omawianych historyków, Hartknoch był pod silnym wpływem zachodnich ośrodków protestanckich. Pomimo to zachował obiektywny stosunek do dziejów Kościoła. Jeszcze do końca XVIII wieku był wzorem dla historyków luterańskich w Prusach. Najważniejsze jego dziela: „Respublica Polonica duobus libris illustrata”, Frankfurt-Lipsk 1678 (następne edycje - jenańska z roku 1687 i lipska z 1698 noszą tytut: „De respublica Polonica”), „Preussische Kirchen Historie...” Gdańsk 1686, „Alt und Neues Preussen...” Króle- 
wiec 1684, „Selectae dissertationes historicae de variis rebus prusicis opera...”, bm. 1679 i edycja kroniki Dusburga: „Chronicon Prussiae” Frankfurt $1679^{5}$.

Stanisław Łubieński, żyjący w latach 1573-1640, ukończył szkołę jezuicką w Kaliszu, a nastepnie po studiach zagranicznych w Grazu, Rzymie, Perugii i powtórnie w Rzymie, uzyskał tytuł doktora obojga praw. Od roku 1591 pełnił funkcję sekretarza królewskiego. Był opatem komendatoryjnym w Tyńcu, następnie biskupem łuckim i płockim. Jako biskup łucki posiadał pieczęć mniejszą w Koronie. Należał do najbardziej wykształconych biskupów w Rzeczypospolitej. Najważniejsze jego dzieła: „Brevis narratio profectionis in Sueciam Sigismundi III ...”, 1593, „De motu civili in Polonia libri quatuor”, „Series, vitae, res gestes episcoporum Plocensium...", Kraków 1642. Wszystkie prace Łubieńskiego wydane zostały w „Opera posthuma", Antwerpia $1643^{6}$.

Andrzej Samuel Nakielski, żyjący w latach 1584-1642, był kanonikiem regularnym kongregacji Bożego Grobu w Miechowie. Ukończył wydział sztuk wyzwolonych w Akademii Krakowskiej, zaś po studiach w rzymskiej Sapienzy otrzymał doktorat teologii. W roku 1625 wydał w Krakowie dzieło dotyczące dziejów jego kongregacji zakonnej w świecie: „De sacra antiquitate et statu ordinis... custodum... Sepulchri Hierosolymitani”, zaś w roku 1634 wydał w Krakowie dzieło poświęcone tej kongregacji w Polsce: „Miechovia sive promptuarium antiquitatum monasterii Miechoviensi"' . Dzieło to wydane w 1634 roku, zawiera nie rozstrzy gniętą zagadkę edytorską, gdyż jego treść sięga aż do roku 1646.

Paweł Piasecki, żyjący w latach 1579-1649, opat komendatoryjny w Mogile, biskup kamieniecki, chełmski i przemyski studiował w Rzymie, Ołomuńcu, Pradze, Wiedniu, następnie znowu w Rzymie, gdzie na Sapienzy uzyskał tytuł doktora praw. obojga. Zanim został biskupem prowadził poưfne rokowania z posłem hiszpańskim d'Auchy w sprawie zasiłków na budowę floty polskiej. Był przeciwnikiem polityki prohabsburskiej Zygmunta III. Piasecki wydał w Krakowie w roku 1645 główne swoje dzieło: "Chronica gestorum in Europa singularium”, w którym jako jedyny z historyków polskich XVII wieku dość obszernie przedstawił wydarzenia polskie w kontekście wydarzeń europejskich. Pozostawił także w rękopisie traktat polityczny: "Responsum de absoluto dominio"8.

Szymon Starowolski (1588-1656), kanonik krakowski i polihistor, pozostawił po sobie imponujący dorobek pisarski. W wielu swoich pracach eksponował zagadnienie książki w różnych aspektach problemowych. Szczególnie można to zaobserwować w takich dziełach, jak: „Scriptorum Polonicarum hecatontas...", Frankfurt 1625, „Penu historicum seu dextra et fructuosa ratione historias legendi commentarius", Wenecja 1520, czy "Epitome conciliorum...", Rzym 1653. Starowolski studiował na wydziale sztuk wyzwolonych Akademii Krakowskiej, gdzie otrzymał stopień bakałarza. Był sekretarzem Karola Chodkiewicza. Kilkakrotnie przebywał za granicą w Niemczech, Niderlandach, Francji i Italii ${ }^{9}$.

Stanislaw Szczygielski (1616-1687) rozpocząl studia w Akademii Krakowskiej, a ukończył w Wileńskiej, uzyskując tytuł doktora filozofii. Przypuszczalnie studiował za granica, między innymi w Pradze. Po wstappieniu do zakonu benedyktyńskiego, bezgranicznie był oddany temu zgromadzeniu. Na podstawie archiwaliów napisał monografię opactwa tynieckiego: "Tinecia seu historia Monasterii Tinieciensis", 
Kraków 1668, zaś dzieje benedyktynów w świecie zawarł w dziele: „Aquila PolonoBenedictina", Kraków 1663. Przyczynił się także do reformy szkoły i biblioteki tynieckiej $^{10}$.

Omawiani badacze wykorzystywali ksiażki jako źródło historyczne do prowadzonych przez siebie studiów. Dla podkreślenia ważności pewnych tytułów, niektórzy z nich, umieszczali je (chociaż w sposób dalece niepoprawny w stosunku do norm bibliograficznych) na początku swoich prac, tworząc omówienia bibliograficzne. Najlepiej czynił to Hartknoch, gorzej Starowolski, Szczygielski i Nakielski. Każde omówienie bibliograficzne zawiera poważne usterki. Zdarza się często, iż wspomniani historycy wymieniali jedynie autora, innym razem sam tytuł dzieła i to zniekształcony. Bywało, że zamiast nazwiska autora figurował wydawca. Do rzadkości należało wymienianie miejsca i roku wydania.

Najbardziej klarowne próby tworzenia omówień bibliograficznych spotykamy u Jana Krzysztofa Hartknocha w „Respublica Polonica”, wydanie z roku 1678 i następne z roku 1687 oraz 1698. Także w dziele: „Selectae dissertationes historicae de variis rebus opera" znajdujemy na początku dzieła dość rozbudowane omówienie bibliograficzne.

Brak miejsca nie pozwala, i nie wydaje się to celowe, by wymieniać wszystkie pozycje przedstawione w analizowanych omówieniach bibliograficznych. Słuszniejszym będzie zwrócenie uwagi na sposób przedstawiania książek zawartych w tych omówieniach. Przede wszystkim spotykamy się z opiniami wyrażanymi przez autorów prac na temat zawartości ksiażek przez nich przedstawionych. Spotykamy się z charakterystykami biograficznymi autorów, omówieniami materiału pisarskiego ksiązki, zwracaniem uwagi na druk, oprawę, format i czasami na miejsce wydania oraz na to, czy jest to oryginał, kopia, rękopis. Najbardziej te zagadnienia uwzględnia Hartknoch.

W dziele „Respublica Polonica” znajdujemy dwa omówienia bibliograficzne. W pierwszym Hartknoch wymienia ksiażki napisane przez historyków polskich. Posługując się terminologią źródłoznawczą można powiedzieć, iż eksponuje źródła narracyjne. W drugim natomiast wymienia dzieła zawierające dokumenty, czyli w ujęciu źródłoznawczym eksponuje źródła aktowe.

Kolejność prezentowanych dzieł podyktowana jest względami chronologicznymi. Hartknoch przedstawia według własnego uznania książki ukazujące się od czasów najdawniejszych aż do najnowszych. Czyni uwagi o autorach. Np. pisze, iż Kadłubek był biskupem krakowskim, Heidenstein sekretarzem królewskim, Jan Herburt z Felsztyna kasztelanem sanockim, Paweł Piasecki biskupem przemyskim (pomija jego wcześniejsze stolice w Krzemieńcu i Chełmie), Kobierzycki kasztelanem gdańskim i wojewodą pomorskim, Jan Łaski kasztelanem koronnym i arcybiskupem gnieźnieńskim. O Baszce pisze, ale tylko w pierwszym wydaniu: „antiquissimus scriptor".

Hartknoch, chociaż nie zawsze, podaje miejsce wydania dzieła. Np. pisze, że kronika Kadłubka została wydana w Dobromilu w 1615 roku wraz z komentarzem. Pisze, że dzieło Miechowity: "Chronica Polonorum” znalazło się w II tomie J. Pistoriusa: „Poloniae historiae corpus”, Bazylea 1582 (nie wspomina o wcześniejszych edycjach krajowych, Kraków 1519, 1521). Niekiedy podaje format dziela, jak 
np. w przypadku kroniki Piaseckiego - folio, Nagebauera - quarto, Długosza octavo, Pastoriusa - duodecimo.

Hartknoch wspomina o przedrukach dzieł. Np. przedstawiając „Annales Polonici" Stanisława Orzechowskiego wydane w Gdańsku w 1643 roku stwierdza, że edycja ta stanowi przedruk wydania dobromilskiego (wydawca Harburt 1611 r.). Także popełnia błąd, wspominając o Piotrkowczyku wydawcy, jako autorze.

W następnych edycjach wspomnianego dzieła Hartknoch dokonuje uzupełnienia omówień bibliograficznych oraz dokonuje korekty pomyłek, jakie mu się przytrafily w pierwszym wydaniu. Przede wszystkim Baszko przestaje figurować na pierwszym miejscu i znika przy nim określenie „antiquissimus scriptor”. Na pierwszym miejscu wymieniany jest Kadłubek. Hartknoch poszerza informacje biograficzne o nim dodając, że po rezygnacji z biskupstwa został mnichem jędrzejowskim.

Biogram Długosza uzupełnia informacja, iż napisał on „Vitae episcoporum Posnaniensium", które kontynuował Jakub Brzemeski (Brzeziński), zaś wydał Tomasz Treter. Ponadto informuje o Długoszu, że pisał żywoty biskupów płockich, które zostały opublikowane w „Opera posthuma" Łubieńskiego. Hartknoch uzupełnia wykaz pozycji o kronikę Bernarda Wapowskiego, podając wzmianki biograficzne o jej autorze oraz pisząc, iż wydał ją Tomasz Płaza. W innym omówieniu, dotyczącym źródeł umownie nazywanych aktowymi, wymienia dwa zbiory konstytucji wydanych przez Ładowskiego i Piotrkowczyka.

W innym dziele: „Selectae dissertationes historicae de varii rebus Prussicis...", bm. 1679 Hartknoch podaje również omówienie bibliograficzne, w którym jak gdyby wyodrębnia dwie części. Najpierw podaje tytuły, co do których ma wątpliwości czy wspomniane dzieła były w ogóle napisane. Sa to dwa tytuły: "Liber originis et furiarum gentis idiomatae Brutorum..." Jarosława z Płocka i dzieło nie wymienionego z nazwiska biskupa chełmińskiego: „Liber filiarum Balial...". Następnie Hartknoch podaje te dzieła, co do których istnienia nie ma wątpliwości. Przy tym czyni dość istotne zastrzeżenia, iż o niektórych dziełach tylko słyszał (wtedy powołuje się na informatorów), a z pozostałymi zetknął się osobiście. Ten wykaz Hartknoch dzieli na trzy grupy. W pierwszej znalazły się dzieła autorów krzyżackich, pruskich i gdańskich do końca XVI wieku, w drugiej dzieła siedemnastowieczne tej grupy autorów i wreszcie w trzeciej - dzieła autorów polskich. Tu wymienia Hartknoch tylko tych polskich historyków, którzy jego zdaniem omawiali zagadnienia dotyczące spraw krzyżackich oraz pruskich. Podaje nazwiska Kadłubka, Długosza, Miechowity, Kromera, Stryjkowskiego, Gwagnina, zaznaczając, że najważniejszym pisarzem jest Stryjkowski.

Gdy śledzimy wykaz Hartknocha, nasuwa się spostrzeżenie, iż autor akcentuje pewne zagadnienia. Przede wszystkim w skróconej formie omawia treść dzieła i podaje okres czasowy jakiego ono dotyczyło. Np. pisze, że brat zakonu krzyżackiego Wingrand z Marburga napisał kronikę zakonu obejmującą wydarzenia do roku 1388. Oficjał risengburski Johannes Lindenbladt napisał kronikę zakonu od czasów Vinrica do czasów Konrada Erlichshausena oraz że opisał on wojnę trzydziestoletnią. Przedstawiając anonimowy kodeks dotyczący biskupów warmińskich, a będący $w$ jego posiadaniu, autor stwierdza, iż $w$ tym kodeksie znajduje się wiele dokumentów papieskich. Prezentując inny anonimowy kodeks Hartknoch pisze, iż 
stanowi on niedokładne tłumaczenie $z$ łaciny na niemiecki kroniki Dusburga, wraz z dodatkiem, w którym są opisane wydarzenia zaszle po faktach podanych przez Dusburga. Autor dostrzega kontrast między wydarzeniami podawanymi przez Dusburga, które są opisywane w sposób szczegółowy i kontynuacją jego kroniki, napisaną przez kontynuatora w sposób pobieżny.

Hartknoch wzmiankuje lakonicznie o źródlach na jakich opierali się autorzy, pisząc wymienione przezeń książki. Np. kiedy wspomina o Jeroschinie wzmiankuje, iż jego kronika jest wiernym przekładem z łacińskiego na niemiecki kroniki Dusburga. Przy dziekanie królewieckim Paulu Polesie stwierdza, iż sporządzł on w roku 1532 swoją kronikę w oparciu o różne rękopisy. O żywotach biskupów warmińskich Tomasza Tretera pisze, iż autor wydał je opierając się na napisanej w języku niemieckim książce dziekana warmińskiego Jana Kreczmera. Hartknoch stwierdza, iż dzieło kapłana toruńskiego Alexiusa z Nieświeża: „Liber antiquitatum vitae et mortis gentis Brutonorum..." stanowi upiększanie wywodów Dusburga.

W omówieniu bibliograficznym Hartknocha znajdujemy informacje o autorach. Np. pisze, iż Simon Grunowius pochodził z zakonu dominikańskiego (predikatorów), Kacper Schütz był sekretarzem Gdańska, podobnie jak Reinhold Curike. Przy Piotrze Dusburgu Hartknoch odnosi się polemicznie do informacji podawanej o nim przez Wijuk Kojałowicza, jakoby należał do zakonu Kawalerów Mieczowych. W przeciwieństwie do dzieła „Respublica Polonica” Hartknoch w „Selectae dissertationes..." podaje więcej informacji dotyczących autorów polskich. Np. przy Kadłubku stwierdza, iż napisał on kronikę z rozkazu Kazimierza Sprawiedliwego w stylu surowym. O "Annales" Długosza pisze, iż pierwszy tom wydano w Dobromilu w 1615 roku, zaś inne ksiażki tego autora widział Hartknoch w klasztorze dominikańskim w Gdańsku. Miechowite przedstawia jako doktora astrologii i medycyny, odsyłając czytelnika do Stryjkowskiego na temat danych biograficznych o nim. Kromera charakteryzuje jako człowieka wielkiej erudycji, stwierdzając, że jego historię należy koniecznie zobaczyć. Przy Stryjkowskim pisze, iż zwiedził wiele części Europy, Azji i Afryki.

Gdy Hartknoch wspomina o przekładach dzieł porusza zagadnienie rzetelności tłumaczenia. Np. pisze, że dzieło Jeroschina stanowi wierny przekład Dusburga.

Autor wypowiada się na temat ocen z jakimi spotyka się prezentowana przezeń książka u innych badaczy. Przedstawiając kronikę Grunowiusa stwierdza, iż wysoką ocenę dał jej jezuita z Olsztynka Tomasz Clagius w książce: „Linda Maria sive de B. Virgine Lindensi, Libri V' (Kolonia 1559).

Hartknoch interesuje się także wydawaniem dzieł. Np. pisze, że 10 rozdziałów kroniki Kaspra Schūtza ujrzało światło dzienne, a pozostałych 7 jeszcze nie. Pisze też o różnych edycjach, na przykład, że kronika Georgiusa Ramisa: „Kurtze Erzehlungen der Hohemistre deutsches Ordines" była najpierw wydana anonimowo w Elblągu, a następnie w roku 1564 przez elbląskiego typografa Wolfganga Dietmara. O książce Marcina Murzyńskiego ( Muriniusa) Hartknoch pisze, iż dzieło ("Kronika mistrzów pruskich”, Toruń 1582) zostało najpienw napisane w języku niemieckim, następnie autor przetłumaczył je na język polski, w którym zostało wydane drukiem. Kiedy wszystkie egzemplarze rozprowadzono w Prusach i Pol- 
sce, krakowski drukarz Szymon Kempini przygotowal nową edycję dzieła. (O tym nie ma wzmianki w Bibliografii Finkla.)

Hartknoch mówi o dwu edycjach listu duchownego oleckiego Jana Melitiusa do pienwszego rektora Akademii Królewieckiej Jerzego Sabinusa z roku 1551 i 1553.

Wreszcie możemy się spotkać u Hartknocha z wypowiedzią na temat strony zewnętrznej książki. Mówiąc o posiadanym przez siebie kodeksie, zawierającym przekład kroniki Dusburga, stwierdza, że jest to kodeks pergaminowy, elegancko oprawiony.

Szymon Starowolski we wstępie do: „Epitome conciliorum...” także zamieszcza omówienia bibliograficzne. Odrębnym zagadnieniem, które posiada swoją literatu$\mathrm{re}^{11}$, lecz wykracza poza zakres niniejszych rozważań, jest wkład Starowolskiego w kształtowanie bibliografii narodowej. Te kwestie zostaną tu pominięte.

W „Epitome conciliorum..." możemy wyodrębnić trzy omówienia bibliograficzne. W pierwszym znalazły się najważniejsze, zdaniem autora, dzieła poświęcone dziejom Kościoła i soborów. Informacja o tych dziełach jest szczątkowa, gdyż Starowolski wymienia jedynie czterech aútorów: C. Baroniusza, A. Bzowskiego, A. Chacona i Serviniusa Biniusa.

W następnym omówieniu autor wymienia w kolejności chronologicznej, jak się domyślam, dzieła poświęcone soborom, od Dioniziusa Exigiusa aż do akt soboru trydenckiego, wydanych w 1603 roku przez typografa Dominika Nicolinusa.

Wreszcie w omówieniu trzecim jest literatura poświęcona soborom prowincjonalnym. Nie znajdujemy tam jednak informacji o dziełach odnoszących się do synodów w Polsce.

Starowolski w mniejszym stopniu, aniżeli Hartknoch, dokonuje charakterystyki przedstawianych dziet, jak i podaje mniej informacji na temat ich autorów. Tym niemniej możemy się dopatrywać pewnych analogii. Np. przy Crisconiusie stwierdza, iż posunał do przodu badania nad kanonami soborowymi. Marcina z Braccary przedstawia jako badacza, który w stopniu znaczącym przyczynił się do zbierania informacji o synodach wschodnich, afrykańskich i hiszpańskich. O Gerviniusie Galeniusie pisze, iż materiałów dotyczących soborów szukał w różnych manuskryptach, tworząc kompilacje na wzór Ivona z Chartes, Berharda, Anzelma, Gracjana i Benedykta. Starowolski wysoko ocenia wysiłek badawczy Wawrzyńca Suriusza, pisząc, iż dokonał on uwieńczenia prac poprzednich badaczy, wydając czterotomowe akta synodów generalnych i prowincjonalnych. Na temat autora "Niceorum concilium", Alfonsa z Pizy, pisze, iż był jezuitą oraz, że kanony wspomnianego soboru wydał w oparciu o listy Juliusza I i częściowo w oparciu o kodeks arabski. Serwiniusza Biniusza uważa Starowolski za najbardziej doświadczonego badacza dziejów Kościoła powszechnego.

Stanisław Szczygielski na początku dziela: „Aquila Polono-Benedictina...” stara się zamieścić omówienie bibliograficzne. Przedstawia w nim różnych autorów. Są tam badacze życia świętych, jak np. Suriusz, kronikarze zakonni, np. Leon z Marsylii, czy Piotr Diacon. Autor wymienia też badaczy dziejów kościoła, np. Baroniusza, Wilhelma z Tyru, Rafaela Volateranusa, Constantina Caietanusa, J. Caramanuela, Gonzalesa z llesco, Bucellina, Gaspara Brunscha. W tym omówieniu bibliograficznym znajdujemy historyków z różnych regionów. Świadczą o tym 
choćby nazwiska Bonfiniusa, Krantza, Joannusa Magnusa, Genebardusa, czy Sabelicusa.

Szczygielski dokonuje sporadycznie omówienia zawartości dzieł, oceny merytorycznej książek, także sporadycznie podaje dane biograficzne dotyczące autorów. Wśród nielicznych tego typu wzmianek znajdujemy informację o Bucellinie, iż jest on najbardziej zasłużonym historiografem zakonnym, a przed nim na tym polu zasłużyli się Trithenius, Genebardus i Sabelicus.

Samuel Nakielski w swoich dziełach: „De sacra antiquitate”, jak i „Miechovii” sporządził na początku omówienia bibliograficzne. Ponieważ zakon Bożogrobców w swej genezie zwiazany był z wyprawami krzyżowymi, w omówieniach bibliograficznych znalazło się najwięcej pozycji poświęconych krucjatom. Nakielski wspomina o takich historykach, jak Wilhelm z Tyru, Robert z Aix, Foulcher z Chartes. Wymienia historyków Kościoła: C. Baroniusza, Nicephora Calixta, J. Sigoniusa, Jana de Nigra Valla, Gabriela Pennotiusa i najbardziej przez siebie cenionego Sylwestra Marulusa. W omówieniach bibliograficznych Nakielskiego są również historycy, którzy zajmowali się historią świecką, jak np. Nauclerus, czy Długosz.

Nakielski jest oszczędny co do informacji na temat treści omawianych przez siebie książek, czy danych biograficznych o ich autorach. Tym niemniej gdzie niegdzie możemy je znaleźć. Np. pisał, iż najbardziej znaczącymi dla niego historykami sa Wilhelm z Tyru i Sylwester Marulus ${ }^{12}$. Na podkreślenie zasługuje fakt przyjętej przez niego zasady, iż nie należy przedstawiać dużej ilości dzieł dotyczących tego samego zagadnienia. Świadczy o tym jego wynurzenie, że dla uniknięcia powtarzania się, będzie tylko podawał najwartościowszych autorów ${ }^{13}$.

W omówionych powyżej zestawieniach bibliograficznych ich twórcy starali się przedstawić, według własnego zdania, najwartościowsze dzieła. Ponadto jeszcze wykorzystali w swoich rozważaniach wiele różnorodnych książek w charakterze źródła historycznego, co zostało szczegółowo omówione w innej pracy, wraz z podaniem dokładnych opisów bibliograficznych ${ }^{14}$. Na temat książki traktowanej jako źródło historyczne u wymienionych badaczy, można najogólniej powiedzieć, iż powoływali się oni na autorów starożytnych, np. Herodota, Tacyta, Józefa Flawiusza, średniowiecznych, renesansowych i współczesnych sobie. W największym stopniu korzystali z książek autorów poiskich, a następnie pisarzy obszarów języków romańskich oraz niemieckiego. Ponadto Piasecki odwołuje się do pisarzy angielskich, a Szczygielski do pisarzy obszaru wpływów hiszpańskich i portugalskich oraz szwedzkich.

Przy wykorzystywaniu książek, jako źródeł historycznych, wspomniani autorzy dokonywali ich merytorycznej oceny. Spotykamy się z krytyką ksiażek. Np. Stanisław Łubieński krytykował dzieła historyczne Ditmara i Damianiego za występujące w nich nieścisłości i przeciwstawiał im dzieło Baroniusza ${ }^{15}$. Podobnie Nakielski, kryłykując Bielskiego przeciwstawiał go Długoszowi i Miechowicie ${ }^{16}$. Natomiast Starowolski, gdy krytycznie odnosił się do Platiny, przeciwstawiał mu Bzowskie$\mathrm{go}^{17}$. Ten sam autor nie darzył zaufaniem Focjusza z powodu fałszowania przezeń źródel ${ }^{18}$. Również Łubieński zarzucał fałszerstwo Ditmarowi ${ }^{19}$.

Równocześnie omawiani badacze chwalili uznawane przez siebie ksiąziki. Np. Nakielski wysoko cenił kronikę Miechowity, ponieważ jej autor oparł się na auten- 
tycznych reskryptach klasztoru miechowskigo ${ }^{20}$. W podobnym duchu wyrażał się Starowolski o „Series episcoporum Gnesnensium" Damalewicza, wskazując na wykorzystanie przez autora manuskryptów konwentu łowickiego ${ }^{21}$.

W dziełach omawianych pisarzy spotykamy się z ocenami autorów ksiażek. Np. Nakielski uważa Długosza za najwiarygodniejszego badacza dziejów Polski ${ }^{22}$. W innym miejscu przedstawia go jako najbardziej uczonego i najbieglejszego w pisaniu dawnych dziet ${ }^{23}$. Także uznaje Sarnickiego jako wiarygodnego historyka, chociaż zaznacza, iż był protestantem ${ }^{24}$. O Kromerze pisze „acuratissimus scriptor $^{\prime 25}$. Z kolei Starowolski określa Długosza mianem „vir eruditissimus" ${ }^{\prime 26}$.

Autorzy zwracają uwagę na walory ideowe, styl, estetykę i stronę zewnętrzną książki. Starowolski pisał, iż książka napisana w roku 1518 przez króla angielskiego Henryka VIII, wymierzona przeciw Lutrowi, była najmądrzejszym dziełem jakie ukazało się w tym czasie ${ }^{27}$. Nakielski twierdzil, iż książki Pennotiusa zostały napisane oschłym stylem ${ }^{28}$, natomiast pochlebnie wyrażał się o rękopisach Stanisława Bedy, które zostały napisane w pięknym stylu i zasługują na to, by ujrzały światło dzienne. Starowolski twierdził, iż Kadłubek napisał swą kronikę w stylu wysublimowanym. Innego zdania w tym względzie jest Hartknoch, określając styl Kadiubka jako surowy ${ }^{30}$.

Stroną zewnętrzną książek interesował się szczególnie Szczygielski. W "Tınecii" pisze, iż w bibliotece klasztomej znajdują się setki woluminów z mocnych kart pergaminowych. Inna część książek została napisana na królewskim i cesarskim papierze. Mszały i martyrologia były malowane czerwonym atramentem według zasad sztuki, natomiast postacie występujące w książkach były malowane złotem. Pisze Szczygielski, iż księgi historyczne pochodzące $z$ dawnych czasów są ozdobione wdzięczną kompozycją barw. Szczygielski podaje również informacje dotyczące formatu książek oraz liter. Pisze, iż książki chóralne były pisane na szerokich pergaminowych kartach, belkowymi literami longobardzkimi o przyjemnych inicjałach szerokości piędzi i ozdobione zostały pozłotą szerokości łokcia. Musiały być to bardzo opasłe woluminy, skoro - jak pisze - nie byly do udźwignięcia przez jednego mężczyznę ${ }^{31}$.

Omawiani badacze, zajmując się książą, pragnęli przy pomocy niej wyeksponować cechy intelektualne omawianych przez siebie osób. Poruszali przy tym zagadnienie autorstwa, czytelnictwa, czy też posiadania książki. Tak więc Starowolski przedstawił biskupa Andrzeja Lipskiego, Aleksandra z Hales, Bernarda z Parny, Compostellusa, Mateusza z Paryża, Wiklifa i innych jako autorów książek ${ }^{32}$. Łubieński pisał o autorstwie "Vita Andreae Noscovii" Aleksandra ze Świecia ${ }^{33}$. Z kolei Nakielski wspomina, iż Stanisław z Łowicza zwany Bedą napisał wiele książek, które nie ujrzały światła dziennego ${ }^{34}$.

Autorzy poświęcają uwagę produkcji książek. Wskazują, iż były one pisane za przyzwoleniem, bądź też na konkretne zamównienie. Stefan Damalewicz twierdzi, iż Marcin Boroniusz napisał „Żywoty męczenników" za przyzwoleniem arcybiskupa gnieźnieńskiego Maciejowskiego ${ }^{35}$. Ten sam badacz wskazuje, iż nieznany pleban kościola turkowskiego na polecenie arcybiskupa gnieźnieńskiego z roku 1403 i kapituły gnieźnieńskiej pisał książkę o cudach iłaskach św. Bogumiła ${ }^{36}$. Hartknoch natomiast wzmiankuje, iż Jeroschin z rozkazu Dietricha z Aldenburga dokonał przekładu kroniki Dusburga ${ }^{37}$. 
Przy produkcji książki rękopiśmiennej, autorzy wskazują na zjawisko kopiowania książek. Starowolski pisze o trosce papieża Mikołaja $\vee$ poświęconej kopiowaniu książek, pomimo iż w tym czasie istniała technika drukarska ${ }^{38}$. Nakielski wzmiankuje o prepozycie Waclawie ze Zdziechowa, który w klasztorze miechowskim przepisał własnoręcznie wiele rękopisów ${ }^{39}$. Najwięcej na temat książek pisze w "Tinecii" Szczygielski. Kopiowanie książek łączy on ze względami religijnymi. Wyraża stanowisko, iż prepisywanie ksiażek pomimo istnienia drukarni, stanowi drogę do doskonalenia duchowego zakonników. Jest ono związane $z$ regułą zakonną. Jako wzór do naśladowania w przepisywaniu książek wymienia osoby: Panfila, św. Ambrożego oraz Tritheniusa, który się wsławił tym, iż więcej książek przepisał aniżeli wydał ${ }^{40}$.

Omawianym autorom nie jest obce zagadnienie czytelnictwa ksiązek. Łubieński wskazuje, iż biskup Pstrokoński kształcił swoją formację kapłańską na książce Jana Chryzostoma o kapłaństwie ${ }^{41}$. Z kolei Szczygielski podkreśla rolę czytelnictwa w życiu zakonnym. Pisze on, że Leon Olivetti nakazał benedyktynom czytanie książek i to różnego rodzaju. Najpienw zalecal czytać dzieła religijne, a w dalszej kolejności książki pobożne pisane przez doktorów ${ }^{42}$.

Odrębnym zagadnieniem omawianym przez wspomnianych badaczy są losy ksiaż̇ki. Spotykamy się z problematyką niszczenia książek. Np. Damalewicz wspomina o zniszczeniu przez pożar ksiażki pisanej przez plebana turkowskiego, poświęconej cudom św. Bogumiła ${ }^{43}$. Nakielski, kiedy opisuje pożar klasztoru miechowskiego w 1506 roku wzmiankuje, iż wtedy spłonęły książki oraz dokumenty $^{44}$. Starowolski wskazuje, iż na synodzie rzymskim w 492 roku postanowiono, by oddzielić ksiażki autentyczne od apokryfów. Pisze też o paleniu książek manichejczyków z rozkazu papieża Gelazjusza ${ }^{45}$.

Także na temat bibliotek snują refleksje wymienieni badacze. Starowolski, popełniając błąd, wspomina, iż bibliotekarz papieski Atanazy w czasie pontytikatu Hilarego założyl przy bazylice laterańskiej dwie biblioteki ${ }^{46}$. Nakielski dostarcza informacji, iż kaznodzieja katedry krakowskiej, Sebastian, ofiarowal karmelitom krakowskim swoją bibliotekę ${ }^{47}$. Również ten sam autor pisze, iż prepozyt miechowski Stanisław Staiconius sprawił dla biblioteki miechowskiej różne książki o treści prawniczej, prawa kanonicznego oraz teologiczne ${ }^{48}$. Informuje także o ofiarowaniu dla biblioteki miechowskiej własnego prywatnego księgozbioru, jak podkreśla, obejmujacego dobrych autorów, przez dziekana katedry Iwowskiej - Jana Baranowskiego $^{49}$. Wreszcie Nakielski podaje wiadomość, iż prepozyt klasztoru św. Jadwigi w Krakowie ofiarował klasztorowi miechowskiemu 60 woluminów ksiązek ${ }^{50}$.

Autorzy różnie się wypowiadają na temat rabunku biblioteki heidelberdzkiej w okresie wojny trzydziestoletniej. Starowolski, nie zauważając procederu, wspomina o zapobiegliwości Urbana VIII, pisząc, iż dzięki niej wzbogacił bibliotekę papieską manuskryptami sprowadzonymi z Niemiec ${ }^{51}$. Bardziej konkretnie i zgodnie z prawda przedstawia to wydarzenie Piasecki, mówiąc o zrabowaniu tej biblioteki przez księcia bawarskiego, a następnie $w$ dalszej kolejności o przekazaniu jej papieżowi ${ }^{52}$.

Dotychczasowe rozważania ukazały różnorakie aspekty omawianej problematyki. Dla wszystkich wyszczególnionych badaczy, a zwłaszcza dla Hartknocha, Nakielskiego, Szczygielskiego i Starowolskiego, ksiażka stanowiła źródło history- 
czne. Dokonywali oni merytorycznej oceny książek, z czym można spotkać się szczególnie u Łubieńskiego, Nakielskiego, Szczygielskiego i Starowolskiego. Także sporadycznie spotykamy się z omawianiem strony zewnętrznej książki. Występuje ono u Hartknocha, Szczygielskiego i Starowolskiego. Dwaj ostatni interesowali się także stroną estetyczną książek. Każdy z omawianych badaczy zajłmował się losami książki.

\section{Przypisy}

${ }^{1}$ Niniejsza rozprawa stanowi uzupelnienie wyników badań zawartych w przyjętym do druku artykule: Książka w pracach historyków polskich XVII wieku, [W:] "Annales Universitatis Mariae Curie Skłodowska", sectio F. We wspomnianym artykule jest petny opis bibliograficzny tych dzjet, o których wspominali omawiani historycy. $Z$ braku miejsca rezygnuję $z$ podawania pehnego opisu.

${ }^{2}$ J. Serczyk, Warsztat historyczny Jana Krzysztofa Hartknocha (1644-1687), W:] Księga pamiątkowa 400-lecia Toruńskiego Gimnazjum Akademickiego, t. 1, Toruń 1972, s. 290.

${ }^{3}$ O. Ranum, Artisans of Glory. Writers and Historical Thought in Seventeenth Century, University Carolina Press 1980, s. 25. Autor pisze, iż tacy historycy, jak D.L.T. Godefroy, A.F. Duchesne, J.P. Dupuy, E. Baluze, C. du Cange byli bibliotekarzami.

${ }^{4}$ A. Morawski, Biogram S. Damalewicza, [W:] Polski slownik biograficzny, t. 4, Kraków 1938, s. 396-397.

5 J. Serczyk, op. cit., s. 283.

${ }^{6}$ W. Czapliński, Biogram S. Łubieńskiego, [W:] Polski slownik biograficzny, t. 18, Wrocław 1973, s. 498-500.

${ }^{7}$ H.W. Wyczawski, Biogram S. Nakielskiego, [W:] Polski słownik biograficzny, t. 22, Wrockaw 1977 , s. $468-469$.

8. W. Czapliński, Biogram P. Piaseckiego, [W:] Polski słownik biograficzny, t. 25, Wroclaw 1977, s. 787-789.

${ }^{9}$ L. Hajdukiewicz, Biogram S. Starowolskiego, [W:] Historia nauki polskiej, pod red. B. Suchodolskiego. T. VI. Dokumentacja biobibliograficzna. Indeks biograficzny t. 1-2, Wroclaw 1974, s. 643-644.

${ }^{10}$ L. Hajdukiewicz, Biogram S. Szczygielskiego, tamże, s. 674 (niektórzy pisarze używają pisowni nazwiska Sczygielski).

${ }^{11}$ F. Bielak, Działalność naukowa Szymona Starowolskiego, Warszawa 1957; J. Starnawski, Szymona Starowolskiego hekatontas i początki bibliografii polskiej, "Roczniki humanistyczne", vol. 12, Lublin 1964, s. 136; J. Korpała, Dzieje bibliografii w Polsce, Warszawa 1969, s. 47-51.

${ }^{12}$ S. Nakielski, De sacra antiquitate... custodum... Sepulchri Hierosolymitani, Kraków 1623, s. 3.

${ }^{13}$ Tamże, s. 25.

${ }^{14}$ por. przypis 1.

${ }^{15}$ S. tubieński, Responsio..., [W:] Opera posthuma, Antwerpia 1643, s. 311.

${ }^{16}$ S. Nakielski, De sacra..., s. 151.

${ }^{17} \mathrm{~S}$. Starowolski, Epitome conciliorum tam generalium quam provincialium in Greca et Latina Ecclesia elaboratum, Rzym 1653, s. 360.

${ }^{18}$ Tamże, s. 233.

${ }^{19}$ S. Łubieński, op. cit., s. 312.

${ }^{20} \mathrm{~S}$. Nakielski, Miechovia sive promptuarium antiquitatum monasterii Miechoviensis, Kraków 1634, s. 323. 
${ }^{21}$ S. Starowolski, Vitae antistitum Cracoviensium..., Kraków 1655, s. 156. Por. Estr., t. 29, s. 212.

${ }^{22}$ S. Nakielski, Miechovia..., s. 60.

23 Tamże, s. 111.

24 Tamże, s. 150.

25 Tamże, s. 150.

${ }^{26} \mathrm{~S}$. Starowolski, Vita et miracula servi Dei Vincenti Kadłubkonis..., Kraków 1642, s. 37. Por. Estr., t. 29, s. 212.

27 S. Starowolski, Epitome..., s. 361.

${ }^{28}$ S. Nakielski, Miechovia..., s. 60.

29 Tamże, s. 351.

${ }^{30}$ S. Starowolski, Vita et miracula..., s. 32-33; J.K. Hartknoch, De respublica Polonica..., FrankfurtLipsk 1687, 5. 8.

${ }^{31} \mathrm{~S}$. Szczygielski, Tinecia seu historia monasterii Tinecensis..., Kraków 1668, s. 234-238.

${ }^{32}$ S. Starowolski, Vitae antistitum..., s. 28; tenże. Epitome..., s. 246, 328.

${ }^{33}$ S. Kubieński, Vita Pstroconii..., [W:] Opera..., s. 377.

${ }^{34}$ S. Nakielski, Miechovia..., s. 467.

${ }^{35}$ S. Damalewicz, Historia świętobliwego życia błogosławionego Bogumiła, Kalisz 1748, s. 155-156.

${ }^{36}$ S. Damalewicz, tamże, s. 152.

${ }^{37}$. J.K. Hartknoch, Selecte dissertationes historicae de variis rebus prusicis opera..., bm. 1679, wstęp.

${ }^{38}$ S. Starowolski, Epitome..., s. 355.

${ }^{39}$ S. Nakielski, Miechovia..., s. 467.

${ }^{40} \mathrm{~S}$. Szczygielski, Tinecia..., s. 434-438.

${ }^{41}$ S. Łubieríski, Vita Pstrokonii..., [W:] Opera..., s. 245.

${ }^{42}$ S. Szczygielski, Aquila Polono-Benedictina..., Kraków 1663, s. 169.

${ }^{43}$ S. Damalewicz, Historia świętobliwego..., s. 152.

${ }^{44}$ S. Nakielski, Miechovia..., s. 942.

${ }^{45}$ S. Starowolski, Epitome..., s. 68.

46 Tamże, s. 64.

${ }^{47}$ S. Nakielski, Miechovia..., s. 942.

48 Tamże, s. 351.

49 Tamże, s. 940.

50 Tamże, s. 542.

${ }^{51}$ S. Starowolski, Epitome..., s. 382.

52 P. Piasecki, Chronica gestorum in Europa singularium..., Kraków 1645, s. 425, 436. 